\title{
Alfred Kahn as a Case Study of a Political Entrepreneur: An Essay in Honour of his 90th Birthday
}

\author{
PHILIP J. WEISER * \\ Professor of Law and Telecommunications, University of Colorado
}

\begin{abstract}
The success of airline deregulation challenged the claims of public choice theory, which asserts that regulation serves the purposes of the regulated firms themselves. One prominent explanation for airline deregulation is that "political entrepreneurs" can, under certain circumstances, challenge the status quo. Nonetheless, commentators have failed to examine how Fred Kahn fits the model of a political entrepreneur. By examining Kahn's success as a political entrepreneur, this Essay highlights how commentators and policymakers can gain important insights into how to spur regulatory reform and oversee regulatory reform efforts like that necessary to modernize our system of spectrum management.
\end{abstract}

\section{Introduction}

On many accounts, Alfred Kahn is the seminal figure in regulation in the United States during the late 20th and early-21st century (McCraw, 1984). As a regulator, as an academic, and as an advocate, Fred Kahn has been preeminent in each of these roles, and shaped the way that institutions behave, academics study and, most importantly, regulators regulate. Not only did he write the book (or a two-volume treatise, as it were) on the Economics of Regulation (Kahn, 1970), he also wrote and executed the play book on how to conceive of and manage a major deregulatory initiative as a "political entrepreneur". In so doing, he underscored that ideas and effective public administration can make a difference - proving wrong those skeptics who doubted that regulatory reform could ever be accomplished over the wishes of vested interests who benefit from the status quo. ${ }^{1}$

Kahn's leadership as a political entrepreneur is a topic that commentators generally gloss over, offering only a sentence or two to note that Kahn fits the prototype (Peltzman et al, 1989). The concept of a political entrepreneur continues to be developed and is currently used to cover a range of actors, including consumer advocates like Ralph Nader (who famously pushed for auto safety regulations), politicians like Ed Muskie (who spearheaded the drive for environmental protection), and, in a few cases, regulators like

\footnotetext{
* University of Colorado Law School. 404 Wolf Law Building, 401 UCB, Boulder, CO 80309-0401. E-mail: phil.weiser@colorado.edu. Thanks to Brad Bernthal, Andrew Crain, Ray Gifford, Ellen Goodman, Jon Nuechterlein, Adam Peters, Jim Speta, Tim Tardiff, Heidi Wald, Dennis Weisman, and an anonymous referee for helpful comments and encouragement, and to Dan McCormick for outstanding research support.

${ }^{1}$ Notably, I do not take a position on the costs or benefits of airline deregulation, but rather, I highlight that the very success of the initiative makes it worth studying as a model for effectuating regulatory reform.
} 
Fred Kahn (Pozen, 2008). ${ }^{2}$ In most cases, discussions of political entrepreneurship tend to be more abstract and not grounded in the practical experience of policymakers like Fred Kahn.

This Essay emphasizes the importance of examining case studies in political entrepreneurship. In particular, as to Fred Kahn, a case study of his leadership underscores the importance of developing a public case for regulatory reform, stretching the legal authority of a regulatory agency to pursue reform objectives, and empowering entities that would benefit from reform. Although this Essay does not seek to undertake an exhaustive study of how Kahn embodied these qualities in his leadership of the Civil Aeronautics Board (CAB), Part 2 explains the political entrepreneur concept and highlights how Kahn's leadership at the CAB provides an exemplary case of political entrepreneurship. Building on this explanation, Part 3 suggests some relevant strategies for political entrepreneurship in the area of spectrum policy reform. Finally, Part 4 offers a short conclusion, calling for a greater investigation of Kahn's model of political entrepreneurship and an increased focus on the role of such leadership in advancing the cause of regulatory reform.

\section{The path of airline deregulation and Kahn's political entrepreneurship}

The concept of a political entrepreneur takes, as a starting point, the premise that individual and collective initiative can influence policy outcomes. On more economically determined views of history, such individual initiative is irrelevant. For strict adherents to public choice theory, for example, it is an article of faith that powerful rent-seeking forces use regulation to protect concentrated interests over diffuse ones, thereby making swimming against that tide both foolhardy and irrational. But such a public choice perspective, as the last thirty years of deregulation have shown, is over-determined and needs to be tempered by, among other things, the political entrepreneur concept.

Scholars are still developing the concept of "political entrepreneurship". Over the last three decades, scholars have discussed the concept or variants of it (such as "policy entrepreneurs”), but it remains an under-developed concept. ${ }^{3}$ On many accounts, James Q. Wilson (1975) often receives the credit for the concept, developing it as part of a four part typology (Wilson, 1980). ${ }^{4}$ Notably, Wilson recognized the possibility of "entrepreneurial politics” whereby a political entrepreneur, such as Ralph Nader, can overcome public choice forces and mobilize diffuse interests to support regulation over the opposition of

\footnotetext{
${ }^{2}$ For an even broader conception of the term, see Kingdon (1995, p.204), where he explains that "[political] entrepreneurs are found at many locations; they might be elected officials, career civil servants, lobbyists, academics, or journalists. No one type of participant dominates the pool of entrepreneurs".

${ }^{3}$ As Pozen (2008, p.301) put it, “the phrase 'policy entrepreneur' is [often] invoked without any explanation or references, presumably on the belief that the concept is either self-explanatory or so well known as to make citation pedantic. Not infrequently, authors will use 'policy' interchangeably with 'public', 'political', 'bureaucratic', 'administrative', or some other variant.” Michael Mintrom (2000, p.ix) related, in a similar vein, that although they "have been mentioned in the literature on policymaking, policy entrepreneurs remain ghost-like figures, in need of clearer definition".

${ }^{4}$ Peter Schuck (1981) credits Wilson with developing the concept, but others developed it around the same time (see Walker, 1974).
} 
concentrated interests (that is, the regulated sector). ${ }^{5}$ In short, a quintessential political entrepreneur, like Fred Kahn at the CAB, demonstrates that ideas matter in politics by implementing an effective political strategy to spur policy reform. ${ }^{6}$

For my purposes, there are three essential elements - all embodied by Kahn's leadership at the $\mathrm{CAB}$ - that define the role of a political entrepreneur in spurring policy reform. As a starting point, the critical strategic goal of any political entrepreneur is to develop a sufficient level of public awareness of and support for a policy objective. In Kahn's case, his ability to make the case for reform publicly and with intellectual credibility was essential to his success - not unlike the ability of an actual inventor to make the case for commercializing her invention. In tandem with the ability to make the case for deregulation to the public, Kahn also pursued the objective of eroding the airline industry's commitment to the legacy regulatory regime by both undermining the manner in which it protected established incumbents and bolstering the strength of those interests that would benefit from deregulation. Roughly analogous to the role of market entrepreneurs, the challenge of articulating the case for reform parallels the need to make the case for funding a business venture whereas the second two objectives present execution challenges that, if managed effectively, demonstrate that the venture can and should succeed.

Kahn's success in pursuing these three goals resulted from a unique set of skills and abilities that he brought to the effort. First, he understood and was an evangelist for airline deregulation. Like a private sector entrepreneur, a political entrepreneur need not be the inventor of a policy strategy, but it is essential that she fully understands it and can credibly explain it. Second, Kahn's level of commitment was singular and determined. In this respect, he understood and embodied Max Weber's (1946, p.128) description of politics as the "strong and slow boring of hard boards. It takes both passion and perspective”.

In 1977, when Kahn was appointed Chairman of the Civil Aeronautics Board (CAB), the incumbent airlines constituted a cartel that the $\mathrm{CAB}$, in effect, protected by insisting on uniform pricing (thereby preventing firms from detecting and engaging in price-cutting) and preventing new entry (thereby preventing them from having to compete with maverick firms). By pursuing a deregulatory initiative against the wishes of the established firms, Kahn challenged the premises of public choice theory, which predicted that any such initiative was doomed to fail. According to public choice theory and, in particular, the allied concept of capture theory, concentrated interests (like the established airline companies) benefit from and dictate the course of regulation to protect their economic rents at the expense of diffuse interests (namely, average consumers). ${ }^{7}$

\footnotetext{
${ }^{5}$ Wilson's (1980) typology provides for three other categories of politics. On his view, public choice politics can be divided into two parts - interest group politics, whereby narrowly dispersed costs and benefits lead to bargaining among affected interests; and client politics, whereby the benefits are concentrated and costs are dispersed. Wilson also highlights that some laws, such as the Social Security Act and the Sherman Act, apply across a wide array of affected parties and are the result of majoritarian politics.

${ }^{6}$ Other commentators have offered a number of different definitions of the concept. Russell Hardin (1982, p.35), for example, explains that "political entrepreneurs are people who, for their own career reasons, find it in their private interest to work to provide collective benefits to relevant groups". Sam Peltzman (1989, p.51), by contrast, focuses on the function of political entrepreneurs, defining them as persons who discover "how to take advantage of the fundamental instability of majority rule within the constraints imposed by the institutional arrangements designed to induce stability."

${ }^{7}$ See Levine (2006, p.270), who related that "airline deregulation was a policy that principally benefited poorly organized consumers and was adopted over the opposition of a relatively small and very well organized group of regulated airlines”.
} 
By late 1970s, public choice theory had discredited the public interest theory of regulation. Its popularity undoubtedly reflected the views among policy observers that it accurately described the ways in which many regulatory agencies operated (Schuck, 1981). Reflecting this perspective, Migue (1977, p.213) suggested that "[i]t seems fair to say that among economists the most widely accepted theory of government regulation is that, as a rule, regulation is acquired by the industry regulated and is designed and operated primarily for its benefit”. George Stigler (1971, p.5), who was a pioneer in public choice theory, stated similarly that "regulation is acquired by the industry and is designed and operated primarily for its benefit”. By successfully overseeing the deregulation of the airlines, Kahn's leadership challenged the premises and predictive power of this theory. ${ }^{8}$ Indeed, as Peter Schuck (1981) put it, the success of airline deregulation undermined the stronger versions of public choice theory such that no refinements could rehabilitate it.

In recounting the events that led to the deregulation of the airline industry, it is clear that a number of forces and actors came together to spur the enactment of the Airline Deregulation Act of 1978 (McCraw, 1984). On all accounts, however, Fred Kahn plays a starring role (McCraw, 1984). For future would-be political entrepreneurs, Kahn's leadership strategies and tactics thus bear close analysis.

The appointment of a world class economist to the CAB defied the tradition of appointing individuals from political backgrounds to regulatory agencies. ${ }^{9}$ In the wake of Watergate, President Carter took seriously his commitment to restore confidence in government and thus broke from precedent by seeking out individuals with intellectual fortitude, expertise, and independence from traditional regulatory politics. ${ }^{10}$ Fred Kahn fit this bill perfectly - with acclaimed experience as a (if not the) leading economist of regulation and as a respected regulator at the New York State Public Service Commission - and he approached his role at the Civil Aeronautics Board with the spirit of a true reformer. Moreover, as an outsider to the airline industry, he viewed both the traditional regulatory agenda and the traditional regulatory processes with skepticism and suspicion. In so doing, he astonished airline executives by refusing to accept conventional wisdom, famously remarking that "I really don't know one plane from the other. To me they are all marginal costs with wings (McCraw, 1984, p.224).”

As to Kahn's substantive agenda, he sought to undermine the traditional premises of airline regulation that competition was destructive and should be avoided through command and control regulation. Rather, he sought to act based on the economic analysis he set forth in his masterful Economics of Regulation (Kahn, 1970). ${ }^{11}$ In the second

\footnotetext{
${ }^{8}$ An early contribution to public choice theory came in Mancur Olson, The Logic Of Collective Action: Public Goods And The Theory Of Groups 1-4 (Harvard University Press 1965). In the early 1970s, a number of seminal articles developed the concept. See George J. Stigler, The Theory of Economic Regulation, 2 Bell J. Econ. \& Mgmt. Sci. 3 (1971); see also Richard A. Posner, Taxation By Regulation, 2 Bell J. Econ. \& Mgmt. Sci. 22 (1971); see also Richard A. Posner, Theories of Economic Regulation, 5 Bell J. Econ. \& Mgmt Sci. 335 (1974).

${ }^{9}$ See J. Landis, Report on Regulatory Agencies to the President-Elect (1960) for a description of the type of individuals appointed to regulatory agencies.

${ }^{10}$ When appointing others to the agency, Carter followed Kahn's guidance to avoid appointing a politician and to select individuals with "a firm, independent professional background and qualifications," and "in a position to make strong, intellectually-grounded professional judgments.” (McCraw, 1984, p.289)

${ }^{11}$ See also Michael E. Levine, Airline Competition in Deregulated Markets: Theory, Firm Strategy, and Public Policy, 4 Yale J. Reg. 393, 394 (1987) for a description of how "by the mid-1970's it was probably fair to say that no impartial academic observer of any standing doubted that the airline business, if unregulated, would reach something that more or less resembled a competitive equilibrium”.
} 
volume of that treatise, Kahn (1971) cited experiments in airline competition undertaken at the state level that underscored the opportunity for discount airline operators to attract new customers and fly planes at much higher load factors than the industry average.

Immediately upon arriving at the $\mathrm{CAB}$, Kahn sought to revolutionize the ways that the agency operated. For starters, he required all communication and orders to be written in understandable prose. In terms of process, Kahn criticized what he viewed as an intellectually bankrupt means of doing business - deciding issues in secret, without deliberation, and asking lawyers to develop the necessary justification for a pre-determined result. ${ }^{12}$ In terms of agency structure, he also reorganized its operations, increased the role of professional economists, and appointed very talented deregulatory minded officials. Like at the New York State Public Service Commission, his leadership at the CAB was not hierarchical, involved recruiting and empowering talented staff, and included efforts to persuade existing professional staff of the merits of his views. In so doing, Kahn realized that the traditional substantive failings of the CAB went hand-in-hand with addressing its procedural flaws and legacy ways of doing business - by restricting competition and awarding benefits to a precious few, it was natural for the agency to operate along political lines as opposed to judicial ones. ${ }^{13}$

At the level of strategy, whether conscious or not, Kahn's overarching objective was to help foster a political environment conducive to regulatory reform. As Michael Levine (2006) describes it, the central challenge that Kahn faced was to overcome the presence of “slack” enjoyed by the legacy regulatory regime. On Levine's (2006) account, slack is the dynamic that creates political cover for regulatory beneficiaries to continue enjoying the benefits accorded to them while the public and their elected representatives are unable to appreciate the economic consequences of regulatory policy decisions. ${ }^{14}$ In an alternative conception of slack, Professor Croley (1998, p.23) explains that "principal-agent 'slack"” is what enables "legislators [or regulators] to 'shirk' - to sacrifice their constituencies' collective interests for their own private goals and interests". On both explanations, slack represents the lack of awareness and attention to substance of the relevant regulatory policies and thus protects the beneficiaries of regulation and stands in the way of regulatory reform.

The reduction of slack is not necessarily something that a single political entrepreneur can accomplish. Rather, as Levine (2006, p.272) puts it: "Regulators can increase or minimize the transaction and information costs involved in monitoring and changing policy, and actors like media, academics, policy entrepreneurs, lobbyists, public interest groups, and politicians looking for an issue can increase or lower these costs through their own behavior." In the case of airline regulation, Kahn benefitted from and entered the

\footnotetext{
${ }^{12}$ In a famous speech to the American Bar Association, Kahn related that the traditional regulatory process involved:

[A] lawyer on the General Counsel's staff, amply supplied with blank legal tablets and a generous selection of clichés - some, like "beyond-area benefits," "route strengthening” or "subsidy need reduction," tried and true, others the desperate product of a feverish imagination - would construct a work of fiction that would then be published as the Board's opinion.

(McCraw, 1984, p.286). This observation anticipates a later scathing critique of FCC regulation by Judge Richard Posner - "the [FCC's] opinion, like a Persian cat with its fur shaved, is alarmingly pale and thin." Schurz Comm, Inc. v. FCC, 982 F.2d 1043, 1050 (7th Cir. 1992).

${ }^{13} \mathrm{Kahn}$ is quoted as stating that "[t]he dispensation of favors to a selected few is a political act, not a judicial one (McCraw, 1984, p.286).”

${ }^{14}$ Levine (2006, p.273 n.9) credits Kalt and Zupan for developing the concept.
} 
surge of congressional interest in the topic that, in turn, "resulted in intense media coverage of the issue from 1976-1978 (Levine and Forrence, 1990, p.195)”. Nonetheless, even if Kahn, acting alone, might have failed to spur regulatory reform, it is clear that his actions at the head of the CAB proved to be a catalyst for regulatory reform. In particular, three distinct aspects of his leadership helped to foster the historic changes that occurred under his watch.

First and foremost, Kahn embraced the role of public advocate for regulatory reform. To be sure, he was fortunate to operate in a climate where other actors were interested in raising awareness about the benefits of deregulation, but his leadership - described by Levine (2006, p.277) as "intellectually powerful, attractive, and mediagenic" - was invaluable. In particular, his credibility stemmed from a widespread confidence that he was not trying to advance any self-serving political or parochial agenda. To that end, his prior academic writings - notably, his calls for airline deregulation in his Economics of Regulation - made him as bullet proof as a Washington inside player can be. And Kahn was not afraid to step into the line of fire, either, as he "testified before Congress, lobbied the White House, engaged the industry in debate, and was very accessible to the media (Levine, 2006, p.277)”. Thus, a considerable part of Kahn's success as a political entrepreneur stemmed from his ability to translate his sophisticated academic understanding of regulation in terms that overcame the general bias that regulatory policy issues are too complex, esoteric, or boring to sustain public attention and concern. ${ }^{15}$ Praising his public relations skills and ability to come up with the right one-liner, Thomas McCraw (1984, p.223) called him the "model of the modern media general".

A second component of Kahn's political entrepreneurship was his willingness to use the CAB's legal authority to move the industry toward deregulation. Notably, the agency took a number of steps to loosen its control over the industry and encourage entry, ${ }^{16}$ thereby both facilitating experiments that made the case for further deregulation, undercut the industry's firm and united stance against deregulation, and made the ultimate move to complete deregulation less drastic for the industry players. Notably, under Kahn's leadership, the agency began, for the first time, to approve and promote the use of discount airfares, which facilitated price competition and improved dramatically the load factors on airplanes. (McGraw, 1984, p.275-77). ${ }^{17}$ Indeed, when Congress enacted its legislation deregulating the industry, it did so recognizing that the law might actually be able to constrain the ongoing deregulatory zeal Kahn had brought to the CAB. ${ }^{18}$ For Kahn, a willingness to use novel strategies was hardly new; at the New York Public Service Commission, he did just that, pioneering what might be called a "negotiated rulemaking", where he told the parties "I hope we can proceed as cooperative seekers of the truth, rather than as adversaries seeking an advantage over one another.” (McCraw, 1984, p.251).

\footnotetext{
${ }^{15}$ As Levine and Forrence (1990, p.190) describe, “Most regulatory issues are highly specialized and do not generate much general attention. Complexity and lack of salience make efforts to overcome slack on regulatory issues - especially issues of economic regulation - particularly costly.”

${ }^{16}$ See, for such an example, Oakland Serv. Case, 78 C.A.B. 593 (1978) (final order).

${ }^{17}$ In fairness to Kahn's predecessor, John Robson, he did oversee the approval of "supersaver" fares on an experimental basis, but it was Kahn who pushed to allow such fares more broadly and on a permanent basis.

${ }^{18}$ As the conference report stated, "Congress expects the deregulation of the aviation industry to move in accordance with this legislation and not in accordance with the, perhaps, differing concepts of some members of the CAB.” H.R. REP. NO. 95-1779, at 56 (1978), as reprinted in 1978 U.S.C.C.A.N. 3773, 3775 .
} 
The third and final component of Kahn's strategy was to identify and bolster the interests and forces vested in deregulation. As Kahn (1990, p.331) explained, one of his goals at the CAB was to bolster the "vested interests in deregulation" on the view that the successful upstarts "having now achieved freedom from regulation, will not readily surrender it". In general, such interests are less well organized than the established interests that benefit from the status quo, meaning that they are uniquely apt to be activated by a political entrepreneur. Again, Kahn had tested this approach out in New York State, where he enlisted a number of groups (including less likely ones like the Environmental Defense Fund as well as a number of utilities) to support his initiative to reform utility rate structures (McCraw, 1984). ${ }^{19}$ In the case of airline deregulation, it was his effort to empower and highlight upstarts like Southwest Airlines as well as to work with United Airlines, which had begun to doubt the wisdom of the legacy regulatory regime, that helped to lay the groundwork for regulatory reform.

\section{Applying the political entrepreneurship model to spectrum regulation}

In many respects, airline regulation and spectrum regulation share some basic characteristics. On some accounts, both regulatory regimes emerged from an effort to protect established interests - the major airlines and the broadcasters - and limited output by restricting the use of the resource in question (Hazlett, 2001 and Keyes, 1951). In both cases, moreover, early academic criticism - famously, Ronald Coase (1959) in the spectrum context - called for regulatory reform that went unheeded (Keyes, 1949). ${ }^{20}$ In the case of spectrum regulation, the movement toward regulatory reform came later, was halting, and remains incomplete. Indeed, Tom Hazlett has criticized the FCC's failure to escape the public choice trap of protecting incumbents by suggesting its initials can best be understood as "Forever Captured by Corporations" (Clark, 2005 and Hazlett, 2001). Part of the challenge facing spectrum reform, like the challenge faced by Kahn at the CAB, is that the FCC itself is not institutionally designed to, among other things, manage spectrum rights in a deregulated, property rights-like manner and thus invites the type of public choice behavior decried by Hazlett. ${ }^{21}$

In the case of spectrum reform, the biggest single force driving regulatory reform and challenging the status quo was the introduction of spectrum auctions. Before 1993, Congress called for the regulation of spectrum as a public trust whereby the Federal Communications Commission would hold comparative hearings to determine what individual or firm merited a license to use the radio spectrum. ${ }^{22}$ In 1993, Congress

\footnotetext{
${ }^{19}$ As McCraw (1984, p.255) reported, Kahn “[w]ork[ed] assiduously over a two year period ... [to] shape[] a political consensus among unusual bedfellows: environmentalists, electric utilities, consumer groups, business firms, and residential customers."

${ }^{20}$ For an interesting study of the progress (and relative lack of progress) in the spectrum reform context, see Shelanski \& Huber (1998).

${ }^{21}$ The FCC's institutional limitations do not only restrict its ability to oversee property rights in spectrum. It also, as I have explained elsewhere, restricts its effectiveness in facilitating the use of unlicensed (or commons) spectrum. See Philip J. Weiser \& Dale N. Hatfield, Policing the Spectrum Commons, 74 Ford. L. Rev. 663 (2005).

${ }^{22}$ This system, as public choice theory would predict, rewarded politically connected firms and made entry more difficult. Among the famous tales of public choice behavior were Lyndon Johnson's ownership of
} 
authorized the FCC to use auctions to assign spectrum licenses and, after the FCC held its first such auction (to assign new blocks of spectrum to be used for second generation (that is, digital) cellular telephony), it generated billions of dollars in revenue for the Treasury. ${ }^{23}$ Congress, recognizing easy money when it saw it, passed a new law requiring that all future assignments of the right to use radio spectrum be determined by an auction that would generate funds for the treasury. ${ }^{24}$

The radio spectrum remains, on almost any account, vastly underutilized. Thus, at the same time when entrepreneurs and users of all stripes are interested in gaining access to spectrum - and many established firms recently paid, in total, \$19 billion for licenses that will become available after the digital TV transition - there is precious little spectrum available. This state of affairs reflects, among other things, that much of the wireless spectrum was allocated to specified uses well before the introduction of auctions and the FCC has historically done very little to ensure that spectrum is being used at all. To its credit, the FCC has authorized the leasing of spectrum licenses. ${ }^{25}$ To date at least, a secondary market in spectrum has developed relatively slowly for bands in which it is authorized and, for many bands of spectrum, spectrum leasing is not allowed at all.

In 2002, the FCC, under Chairman Powell's leadership, sought to reform spectrum policy and, among other things, take aim at the agency's highly conservative and relatively undefined approach to spectrum property rights. ${ }^{26}$ Under the agency's legacy model of regulation, licensees are protected against interference through a set of before-the-fact protective regulations that minimize the possibilities of interference. This means, among other things, that parties seeking additional flexibility must ask the agency to grant them rights to use its spectrum more flexibly - even if they are highly confident (and would put money on it, say, in a performance bond) that the different use would create a negligible, if any, amount of additional interference. During his tenure, Powell did not see any of these initiatives to completion and his successor declined to spearhead them, closing the relevant proceedings without attempting to address the underlying issue.

Powell's spectrum reform effort is notable both for its creative thinking about the need to define property rights in spectrum as well as the lack of any effort to re-think current spectrum allocation decisions. Consider, for example, that Powell did not attempt to develop a framework for enabling UHF TV broadcast licensees to allow other users (such as wireless broadband providers) to gain access to such spectrum. ${ }^{27}$ Similarly, Powell did

\footnotetext{
radio and TV stations in Texas (Lady Bird Johnson was awarded the licenses). For a discussion of this episode, and how spectrum licenses were historically managed, see Nuechterlein \& Weiser (2005).

${ }^{23}$ For the auction revenues collected see CAPCP, FCC Spectrum Auction Data, available at http://econ.la.psu.edu/CAPCP/FCC/index.html

${ }^{24}$ Omnibus Budget Reconciliation Act of 1993, Pub. L. No. 103-66, § 6002 (1993).

${ }^{25}$ Promoting Efficient Use of Spectrum Through Elimination of Barriers to the Development of Secondary Markets, Second Report \& Order, Order on Reconsideration, \& Second Further Notice of Proposed Rulemaking, 19 FCC Rcd. 17,503, 17,505 (2004).

${ }^{26}$ The centrepiece of Powell's reform program was set out in an interagency task force report. See FCC, Spectrum Policy Task Force Report, ET Dkt. No. 02-135 (2002), available at http://hraunfoss.fcc.gov/edocs public/attachmatch/DOC-228542A1.pdf

${ }^{27}$ To be fair, Powell's focus on facilitating the digital TV transition may well have limited his willingness to push on this point. For a discussion of a proposal aimed at addressing this very issue, see Philip J. Weiser, The Untapped Promise of Wireless Spectrum, The Hamilton Project (2008), available at http://www.brookings.edu/ /media/Files/rc/papers/2008/07_wireless_weiser/07_wireless_weiser.pdf
} 
not press - in large part because the FCC lacks jurisdiction over the issue - the question of whether the federal government is effectively using its spectrum. ${ }^{28}$

Future Commissions will confront the opportunity to advance the cause of spectrum reform along a number of possible dimensions. First, as noted above, there needs to be greater scrutiny of whether legacy allocations still make sense in light of the current demand for spectrum for emerging uses, such as wireless broadband. Second, the legacy approach for defining rights to use spectrum is, on all accounts, highly conservative and prevents spectrum from being used more intensively. ${ }^{29}$ Third, there is a huge opportunity to welcome and encourage the development of new technologies, such as "smart radio" technologies, that can provide for more efficient uses of spectrum. Finally, there needs to be greater transparency of what spectrum licenses are out there and how they are being used.

One obvious question is how a future political entrepreneur at the FCC could follow Kahn's example to spearhead successful spectrum policy reform. The threshold and most fundamental challenge that a political entrepreneur would face in spurring spectrum policy reform along the lines discussed above is that the issue has proven politically intractable and incomprehensible to many legislators, let alone, the public at large. The formidable nature of this challenge has led some commentators, such as Jim Speta (2005), to doubt whether spectrum reform is readily achievable.

A political entrepreneur interested in developing the public case for spectrum policy reform confronts two notable challenges. First, many academics continue to debate different strategies (notably, whether to emphasize property rights or unlicensed spectrum), the appropriate tactics necessary to advance a particular strategy (say, whether to use courts or an administrative agency to oversee the use of spectrum property rights), and the proper role of spectrum allocations (what amount of spectrum should continue to be dedicated to over-the-air broadcast, for example). ${ }^{30}$ Second, the entire vocabulary and discourse around spectrum policy is arcane and intimidating to outsiders. Thus, this state of affairs is a product of the culture of telecommunications regulation more broadly where, as Nicholas Lemann (2002) once explained, it is “an insider's game, less because the players are secretive than because the public and the press - encouraged by the players, who speak in jargon - can't get themselves interested”.

For those not well versed in the jargon of spectrum policy, it is difficult to appreciate how the current regulatory discourse clouds the relevant policy stakes of spectrum

\footnotetext{
${ }^{28}$ In a later initiative, the Office of Management and Budget did just that, mandating that government users create and use a "shadow price" that captures the value inherent in their use of spectrum with the aim of dissuading them of the fallacy that their use of spectrum is free. See Office of Management and Budget, "Preparation, Submission, and Execution of the Budget Section 33" Circular No. A-11 (2007), available at http://www.whitehouse.gov/omb/circulars/a11/current_year/a 11_2007.pdf As of this writing, however, it remains to be seen how effectively this requirement will be enforced.

${ }^{29}$ For a critique of this system, see Philip J. Weiser \& Dale Hatfield, Spectrum Policy Reform and the Next Frontier of Property Rights, 15 Geo. Mason L. Rev. 549 (2008). For suggestions of the role that the FCC should play with respect to unlicensed spectrum, see Philip J. Weiser \& Dale N. Hatfield, Policing the Spectrum Commons, 74 Ford. L. Rev. 663 (2005).

${ }^{30}$ Jim Speta (2005 p.185 n. 12 \& 186) discusses the literature of different strategies for spectrum reform. For a sense of the debate on appropriate ways to implement spectrum property rights, compare Philip J. Weiser \& Dale Hatfield, Spectrum Policy Reform and the Next Frontier of Property Rights, 15 Geo. Mason L. Rev. 549 (2008) with Thomas W. Hazlett, A Law \& Economics Approach to Spectrum Property Rights: A Response to Professors Weiser \& Hatfield, 15 Geo. Mason L. Rev. 975 (2008).
} 
regulation. As J.H. Snider (2007) highlights in his article, The Art of Spectrum Lobbying, there is an enormous amount of information related to spectrum licenses - including the basic fact about who holds what licenses - that is not publicly available or, when theoretically available, is discussed in terms that are incomprehensive to anyone other than those very close observers of spectrum policy. The net result of this state of affairs is that the intellectual barriers to entry for understanding spectrum policy are seen as great and the benefits of trying to overcome them are seen as not worth the candle.

Assuming that a political entrepreneur can develop a compelling and popularly accessible rationale for spectrum reform, Kahn's example suggests a few additional prerequisites for the successful implementation of spectrum policy reform. First, it will be important that congressional leadership - like the kind demonstrated by Senator Kennedy with respect to airline deregulation ${ }^{31}$ - emerges to champion the issue. Any such effort will need to pick up on the efforts of others to craft a simple narrative - lower prices or more advanced services for consumers, for example - that can be easily understood by policymakers and the public. Second, a political entrepreneur will need to look for ways to use the FCC's existing authority to pursue reform. Consider, for example, that the FCC has considerable legal latitude to reorient some of its own approaches for defining and enforcing property rights in spectrum. ${ }^{32}$ Third, a political entrepreneur will need to develop support from those likely to benefit from future reform in this area.

Even if a future President taps an FCC Chair who pursues spectrum policy reform with the same level of zeal, political deftness, and intellectual honesty exhibited by Kahn in the case of airline deregulation, she will not succeed unless the overall political climate is receptive to reform. The public's level of interest in an otherwise arcane topic and elected officials' openness to reform depends not merely on the development of an accessible narrative, but also a sense of crisis that renders the narrative compelling and important. With respect to airline deregulation, for example, the presence of rampant inflation provided an impetus for examining regulatory reform strategies that promised to lower the prices of services available to consumers.

The final ingredient of implementing spectrum reform also draws inspiration from Kahn's leadership at the CAB. In particular, if such an opportunity arises, a critical challenge - not unlike Kahn's challenge at the CAB - will be to reform how the FCC operates (that is, its "spectrum culture"). At present, the agency focuses almost entirely on avoiding any potential for interference between users of spectrum, generally relying on the ex ante strategy of instituting protective measures. In so doing, it almost always avoids evaluating the actual uses of spectrum ex post. In this respect, spectrum regulation still largely reflects the command-and-control legacy of an earlier era and has yet to transition fully to a new model of regulation that would make use of adjudication proceedings that evaluate whether interference occurs in practice (and not merely in theory).

\footnotetext{
${ }^{31}$ For a discussion of the importance of the Kennedy hearings, see John W. Kingdon, A Model of Agenda Setting, With Applications, 2001 L. Rev. Mich. St. 331.

${ }^{32}$ For one such example, consider the FCC's reform of its rules governing broadband over powerline systems, where it instituted an after-the-fact assessment strategy in lieu of the traditional use of protective rules. See Amendment of Part 15 Regarding New Requirements and Measurement Guidelines for Access Broadband Over Power Line Systems, Report \& Order, 19 FCC Rcd 21,265, 21,291-96 (2004).
} 


\section{Conclusion}

In this Essay, I have highlighted that regulators have a lot to learn from Fred Kahn. As a political entrepreneur, he informs both the theory and practice of regulation like few others. As a scholar, he has called for evidence-based policy analysis that, on account of his public service, he has demonstrated can be put into practice. In so doing, he has challenged public choice theory's strongest claims and has demonstrated that calls for regulatory reform are not merely tilting at windmills. Despite these accomplishments, scholars have yet to pay sufficient attention to different case studies of political entrepreneurship and Fred Kahn's leadership in particular. By sketching out how regulatory reform in the airline industry reflects the success of Kahn (and others) as a political entrepreneur, this Essay underscores that such studies are worth pursuing.

In closing, I must also acknowledge a quality of Fred's that enabled him to succeed and make him such a special role model - his concern with and engagement with others. Fred is a social person and his interest in a younger generation of regulators and scholars has benefitted numerous individuals (myself among them). For all of those who have gotten to know Fred, his striking combination of a willingness to learn from others, true humility, superb intellect, and terrific sense of humour remind us all not to take ourselves too seriously.

It is all too easy to despair about the state of our politics in general and regulatory reform efforts in particular. But Fred reminds us that such challenges are soluble and that we should undermine the power of ideas and determined leadership. He also leaves us all with the hopeful proposition that we can contribute as much intellectually at any age as he does at 90 !

\section{$5 \quad$ References}

Clark, D. (2005) "Industry Experts Disagree on Best Path to Improve FCC," TechnologyDaily, March 24, available at http://www.nationaljournal.com/pubs/techdaily/pmedition/2005/tp050324.htm

Coase, R.H. (1959) “The Federal Communications Commission,” Journal of Law and Economics, 2: 1-40.

Croley, S.P. (1998) "Theories of Regulation: Incorporating the Administrative Process," Columbia Law Review, 98:1-168.

Hardin, R. (1982) Collective Action. Washington: RFF Press.

Hazlett, T.W. (2001) “The Wireless Craze, The Unlimited Bandwidth Myth, The Spectrum Auction Faux Pas, and the Punchline to Ronald Coase's Big Joke: An Essay on Airwave Allocation Policy,” Harvard Journal of Law and Technology, 14: 335-567.

Kahn, A.E. (1970) The Economics of Regulation: Principles and Institutions. John Wiley \& Sons, Inc.: New York. 
Kahn, A.E. (1971) The Economics of Regulation Volume 2: Institutional Issues. John Wiley \& Sons, Inc.: New York.

Keyes, L.S. (1949) "National Policy Toward Commercial Aviation - Some Basic Problems,” Journal of Air Law and Commerce, 16: 280-97.

Keyes, L.S. (1951) Federal Control of Entry into Air Transportation. Harvard University Press: Cambridge.

Kingdon, J. (1995) Agendas, Alternatives, and Public Policies. Harper Collins: New York.

Lemann, N. (2002) “The Chairman,” The New Yorker. October 7.

Levine, M.E. and J.L. Forrence (1990) "Regulatory Capture, Public Interest, and the Public Agenda Toward a Synthesis,” Journal of Law, Economy and Organization, 6: 167-198.

Levine, M.E. (2006) "Why Weren't The Airlines Reregulated?” Yale Journal on Regulation, 23: 269-297.

McCraw, T. (1984) Prophets of Regulation. Belkap Press: Cambridge.

Migue, J.L. (1977) "Controls Versus Subsidies in the Economic Theory of Regulation," Journal of Law and Economics, 20: 213-21.

Mintrom, M. (2000) Policy Entrepreneurs and School Choice. Georgetown University Press: Washington, D.C.

Nuechterlein, J. and P.J. Weiser (2005) Digital Crossroads. MIT Press: Cambridge.

Peltzman, S., M.E. Levine and R.G. Noll (1989) "Economic Theory of Regulation After a Decade of Deregulation,” Brookings Papers on Economic Activity: Microeconomics, 1989: 1-59.

Pozen, D.E. (2008) “We Are All Entrepreneurs Now,” Wake Forest Law Review, 43: 283340.

Schuck, P.H. (1981) “The Politics of Regulation,” Yale Law Journal, 90: 702-725.

Shelanski, H.A. and P.W. Huber (1998) "Administrative Creation of Property Rights to Radio Spectrum,” Journal of Law and Economics, 41: 581-607.

Speta, J.B. (2005) “Making spectrum Reform Thinkable,” Journal of Telecommunications and High Technology Law, 4: 183-215.

Snider, J.H. (2007) “The Art of Spectrum Lobbying,” New America Foundation Working Paper, available at http://www.newamerica.net/files/WorkingPaper19_SpectrumGiveaway_Snider.pdf

Stigler, G. J. (1971) "The Theory of Economic Regulation," The Bell Journal of Economics and Management Science, 2: 3-21. 
Walker, J.L. (1974) "Performance Gaps, Policy Research, and Political Entrepreneurs: Toward a Theory of agenda Setting,” Policy Study Journal, 3:112-116.

Weber, M. (1946) "Politics as a Vocation," in H.H. Gerth \& C. Wright Mills (ed.), From Max Weber: Essays in Sociology, Oxford University Press: Oxford.

Wilson, J.Q. (1975) “The Politics of Regulation,” in J.W. McKie (ed.), Social Responsibility and the Business Predicament, Brookings Institution Press: Washington.

Wilson, J.Q. (1980) The Politics of Regulation. Basic Books: New York. 